\title{
Pemberian paket gizi masyarakat proyek NICE berpengaruh terhadap kinerja posyandu, tetapi tidak meningkatkan status gizi balita di Provinsi NTB
}

\author{
Effect of NICE project community nutrition package (CNP) supplementation to performance of \\ integrated service post (Posyandu) and nutritional status of children under five at the Province Of \\ Nusa Tenggara Barat (NTB) 2011
}

Solikin', Kristiani², I Made Alit Gunawan³

\begin{abstract}
Background: The province of NTB had the prevalence of underweight $30.5 \%$ in 2010 for children under five, this figure is above the national prevalence. A nutrition improvement through community empowerment (NICE) has been developed aimed to supporting community nutrition service to overcome nutrition and health problem independently. One of the programs is CNP (community nutrition package) which got the highest fund allocation compared to other NICE program.

Objectives: To evaluate the effect of CNP supplementation in NTB Province to the increase of nutritional status of children under five through index of weight by age and performance of posyandu.

Methods: The study was evaluative with quantitative and qualitative method and one group pre and post test design, from January to April 2012 at 4 districts/ municipalities area of NICE Project, comprising 72 villages/cities that received CNP in 533 posyandu with 7,975 of children under fives. Posyandu's performance was measured by baseline data collection for NICE project questionairre, weight measured by scale, and indepth interview was made to individuals administering CNP before and after receiving the package. Samples were randomly selected. Data analysis used paired t-test.

Results: There was significant difference in performance of posyandu ( $p<0.001,95 \%$ Cl: 9.88-11.05) and nutritional status of children under five based on index of weight/age $(p<0.001,95 \% \mathrm{Cl}:-1.23$ to -1.32$)$ before and after CNP supplementation. CNP supplementation increased performance of posyandu, but did not increase the nutritional status of children under five (index of weight/age). There were supporting factors of community nutrition supplementation such as human resources, participation across sectors, villages and community/religious leaders and integration with other programs (PNPM-Mandiri, GSC, local budget). Conclusions: CNP supplementation affected performance of posyandu but did not increase nutritional status of children under five at Province of NTB in 2011.
\end{abstract}

KEYWORDS: NICE project, nutritional status, performance of posyandu, children under five

\begin{abstract}
ABSTRAK
Latar belakang: Provinsi Nusa Tenggara Barat memiliki prevalensi balita underweight di atas prevalensi nasional, yaitu sebesar 30,5 persen tahun 2010. Proyek perbaikan gizi NICE (nutrition improvement through community empowerment) dikembangkan melalui pemberdayaan masyarakat untuk mendukung pelayanan gizi masyarakat. Salah satu programnya adalah paket gizi masyarakat (PGM) yang mendapat alokasi dana paling tinggi dibanding proyek NICE yang lain.

Tujuan: Mengevaluasi pengaruh pemberian PGM di Provinsi NTB terhadap peningkatan status gizi balita indeks berat badan menurut umur dan kinerja posyandu.
\end{abstract}

\footnotetext{
1Dinas Kesehatan Provinsi Nusa Tenggara Barat, Jl. Amir Hamzah No. 103 Mataram, e-mail: ikin_ntb@yahoo.co.id 2Program Studi IImu Kesehatan Masyarakat, Fakultas Kedokteran Universitas Gadjah Mada, JI. Farmako, Sekip Utara Yogyakarta 55281 ${ }^{3}$ Poltekkes Kemenkes Yogyakarta, Jalan Tata Bumi No. 3 Banyuraden, Gamping, Yogyakarta
} 


\begin{abstract}
Metode: Penelitian ini merupakan penelitian evaluatif menggunakan metode kuantitatif dan kualitatif pada bulan Januari sampai dengan April 2012. Penelitian menggunakan rancangan one group pre and post test design. Penelitian dilaksanakan di 4 kabupaten/kota wilayah NICE mencakup 72 desa/kota yang mendapat PGM dengan jumlah posyandu sebanyak 533 dan 7.975 balita. Pengukuran kinerja posyandu menggunakan kuesioner yang diadopsi dari baseline data collection for NICE project, pengukuran berat badan menggunakan dacin dan indepth interview dilakukan pada pengelola PGM sebelum dan sesudah PGM. Pemilihan subjek penelitian dilakukan secara simple random sampling. Analisis data menggunakan paired t-test.

Hasil: Terdapat perbedaan bermakna kinerja posyandu (nilai p<0,001, 95\% Cl: 9,885763-11,05232) dan status gizi balita menurut indeks BB/U (nilai p<0,001, 95\% Cl: -1,233254-1,321063) antara sebelum dan sesudah pemberian PGM. Kinerja posyandu meningkat setelah pemberian PGM, namun belum mampu meningkatkan status gizi balita (indeks BB/U) di Provinsi NTB tahun 2011. Terdapat faktor pendukung pemberian PGM di antaranya kualitas sumber daya manusia (SDM) kelompok gizi masyarakat (KGM), keterlibatan lintas sektor, desa/ kelurahan, dan tokoh masyarakat/agama serta keterpaduan program lainnya (PNPM-Mandiri, GSC, dana daerah).
\end{abstract}

Kesimpulan: Pemberian paket gizi masyarakat berpengaruh terhadap kinerja posyandu tetapi belum mampu meningkatkan status gizi balita di Provinsi NTB tahun 2011.

KATA KUNCI: proyek NICE, status gizi, kinerja posyandu, balita

\section{PENDAHULUAN}

Masalah gizi di Indonesia sampai saat ini masih memprihatinkan, dan terbukti menghambat pertumbuhan ekonomi, berkaitan dengan tingginya angka kematian ibu, bayi dan balita, rendahnya tingkat kecerdasan yang pada akhirnya menyebabkan rendahnya produktivitas, pengangguran dan kemiskinan. Hal ini yang mendasari masalah gizi menjadi salah satu faktor penting penentu pencapaian Millennium Development Goals (MDGs) (1).

Dalam empat tahun terakhir, prevalensi status gizi kurang di Provinsi NTB menurun dari 26,57 persen pada tahun 2007 menjadi 15,83 persen di tahun 2010, sedangkan prevalensi status gizi buruk pada balita meningkat dari 3,45 persen menjadi 4,77\% (2). Masalah gizi disebabkan faktor-faktor ketersediaan pangan dalam rumah tangga, asuhan gizi keluarga dan akses keluarga terhadap pelayanan kesehatan. Halhal tersebut antara lain dipengaruhi oleh menurunnya dukungan pemerintah daerah terhadap program perbaikan gizi di era otonomi daerah, aktivitas posyandu yang menurun, sistem surveilan gizi yang tidak jalan, terbatasnya jumlah dan kualitas tenaga ahli gizi puskesmas, keterbatasan sarana dan prasarana penunjang pelayanan gizi termasuk biaya operasional. Terkait dengan permasalahan tersebut, diperlukan suatu upaya terobosan yang mempunyai daya ungkit tinggi untuk mengatasinya. Upaya yang dikembangkan adalah model perbaikan gizi melalui pemberdayaan masyarakat yang disesuaikan dengan kebutuhan setempat baik di perdesaan maupun di perkotaan. Untuk itu, dilaksanakan proyek perbaikan gizi melalui pemberdayaan masyarakat (nutrition improvement through community empowerment/NICE project) dengan fokus pada penguatan kelembagaan, penyelenggaraan pelayanan gizi terintegrasi, pemberdayaan gizi masyarakat, perluasan program fortifikasi dan komunikasi gizi (1)

Komponen utama proyek ini adalah pemberdayaan gizi masyarakat yang kegiatannya ditujukan untuk mendukung pelayanan gizi masyarakat agar masyarakat secara mandiri dapat mengatasi masalah gizi dan kesehatan sendiri. Pelaksanaan pemberdayaan gizi masyarakat melalui pemberian paket gizi masyarakat (PGM) telah dilengkapi dengan panduan dan petunjuk teknis dari Kementerian Kesehatan R.I. Untuk memperbaiki program-program kesehatan dan pelayanannya, untuk mengantarkan dan mengarahkan alokasi tenaga dan dana untuk program dan pelayanan yang sedang berjalan dan yang akan datang, diperlukan evaluasi terhadap program tersebut (3).

Untuk mengevaluasi pelaksanaan PGM yang dikelola oleh Kelompok Gizi Masyarakat (KGM) di Desa/ Kelurahan Lokasi Proyek NICE dapat berjalan 
dengan baik, memberi hasil sesuai dengan tujuan dan mampu memenuhi kebutuhan sasaran, perlu dilakukan evaluasi secara menyeluruh. Tujuan penelitian ini adalah mengevaluasi pengaruh pemberian paket gizi masyarakat di wilayah proyek NICE terhadap kinerja posyandu dan status gizi balita di Provinsi NTB.

\section{BAHAN DAN METODE}

Jenis penelitian ini adalah penelitian evaluatif dengan menggunakan metode kuantitatif yang diperkuat dengan metode kualitatif untuk melengkapi dan memperjelas hasil analisis kuantitatif. Rancangan penelitian adalah one group pre and post test design.

Penelitian dilakukan di 4 Kabupaten/ Kota di Provinsi Nusa Tenggara Barat, yaitu Kota Mataram, Lombok Barat, Lombok Tengah dan Lombok Timur. Sementara itu jumlah desa/ kelurahan yang dapat menyelesaikan PGM tahun 2011 dan sesuai kriteria inklusi penelitian sebanyak 72 Desa/ Kelurahan dan 533 posyandu sampel dengan jumlah balita yang dianalisis data penimbangannya sebanyak 7.975 balita. Penelitian dilaksanakan mulai Bulan Januari sampai April 2012. Alasan pemilihan lokasi di 4 kabupaten/kota tersebut karena merupakan lokasi terpilih Proyek NICE di Provinsi NTB (1).

Posyandu yang digunakan sebagai unit analisis ditentukan secara purposive yaitu berdasarkan keperluan penelitian.(4). Kriteria inklusi sampel posyandu adalah posyandu yang berada di desa/ kelurahan yang sudah menyelesaikan tahap ketiga paket gizi masyarakat berdasarkan laporan perkembangan proyek NICE tahun 2011. Kriteria eksklusi adalah posyandu yang tidak memiliki laporan penimbangan yang lengkap saat pengumpulan data. Berdasarkan kriteria inklusi dan eksklusi tersebut, diperoleh jumlah sampel posyandu sebanyak 533 dan diperoleh data penimbangan dari 7.975 balita (2).

Di samping analisis kuantitatif terhadap data sekunder berupa status gizi balita dan kinerja posyandu, dilanjutkan dengan pendekatan secara kualitatif untuk menemukan faktor pendukung dan penghambat pelaksanaan program melalui wawancara mendalam (indepth interview) dengan informan yang menjadi subjek penelitian. Subjek penelitian adalah petugas pengelola/pelaksana PGM di tingkat provinsi, kabupaten/kota, tenaga gizi puskesmas, fasilitator masyarakat dan ketua atau bendaharawan KGM sebagai perencana sekaligus pelaksana PGM di desa/ kelurahan.

Variabel bebas (independent variable) dalam penelitian ini adalah PGM, sedangkan variabel terikat (dependent variable) yang merupakan variabel outcome yang dievaluasi meliputi status gizi balita dan kinerja posyandu. Penelitian ini juga menilai komponen input, proses dan output dari variabel PGM (3).

Instrumen yang digunakan pada penelitian ini adalah pedoman wawancara mendalam dan kuesioner atau panduan pengamatan/observasi yang digunakan untuk menggali data dari petugas desa/ kelurahan, KGM, serta kader posyandu. Kuesioner ini diadopsi dari Baseline Data Collection For NICE Project (5). Jenis data yang dikumpulkan berasal dari data primer dan sekunder. Data primer meliputi identitas responden, sedangkan data sekunder yang dikumpulkan terdiri dari kinerja posyandu dan status gizi balita indeks BB/U sebelum dan sesudah pelaksanaan PGM.

Pengumpulan data dibantu oleh asisten peneliti sebanyak 6 orang dan 25 enumerator yang merupakan pegawai dinas kesehatan atau puskesmas yang memenuhi syarat yaitu pendidikan terakhir minimal D-III Kesehatan dan pernah melakukan penelitian. Data dikumpulkan dengan tiga cara yaitu: observasi dengan menggunakan check list di 533 posyandu yang ada di 72 desa/ kelurahan; pengumpulan data penimbangan berat badan menggunakan timbangan dacin terhadap 7.975 balita oleh enumerator, sebelum dan sesudah pemberian PGM; pengisian kuesioner dan panduan wawancara oleh enumerator; dan wawancara mendalam (inldepth interview) dilakukan oleh enumerator dengan menggunakan panduan wawancara mendalam kepada pengelola PGM di dinas kesehatan provinsi, kabupaten/kota, puskesmas dan desa/kelurahan (6); serta melakukan pemeriksaan keabsahan data yaitu triangulasi dengan sumber dengan cara membandingkan data hasil pengamatan dengan data hasil wawancara (7). 
Data yang telah dikumpulkan selanjutnya dilakukan: editing, coding dan tabulasi. Dilakukan analisis univariat yang disajikan dalam bentuk grafik dan tabel dan analisis bivariat dengan paired $t$ test (uji t berpasangan) dengan bantuan software statistic untuk mengetahui perbedaan kinerja posyandu dan status gizi (nilai Z-score indeks BB/U), sebelum dan sesudah pemberian PGM. Data faktor pendukung dan penghambat pelaksanaan PGM dikumpulkan dengan dengan pendekatan secara kualitatif dan eksploratif (6).

\section{HASIL}

\section{Karakteristik posyandu}

Posyandu sampel yang memenuhi kriteria inklusi berjumlah 533 posyandu yang berada di 72 desa/ kelurahan $(87,5 \%$ termasuk desa/ kelurahan siaga) wilayah Proyek NICE. Strata posyandu sampel terbanyak $(61,54 \%)$ termasuk dalam strata madya (Tabel 1).
Pengaruh PGM terhadap peningkatan kinerja posyandu di desa/ kelurahan lokasi proyek NICE

Kinerja posyandu apabila dibandingkan antara sebelum (pre) dengan sesudah (post) pemberian PGM terlihat perbedaan yang nyata, yaitu pengukuran kinerja pada 533 posyandu sebelum pelaksanaan PGM memiliki mean \pm sd $17,42589 \pm 6,0337$ dan pengukuran kinerja setelah pelaksanaan PGM menjadi 27,89493 $\pm 4,20618$, sehingga rerata selisihnya 10,46904 . Hasil uji statistik menggunakan paired t-test menunjukkan adanya pengaruh pemberian paket gizi masyarakat terhadap kinerja posyandu, $(p<0,001 ; 95 \% \mathrm{Cl}$ 9,885763-11,05232).

Kinerja posyandu menjadi kategori baik setelah pemberian PGM karena 5,63\% kinerja posyandu kurang dan $18,20 \%$ kategori sedang sebelum pemberian PGM berubah menjadi kinerja posyandu dengan kategori baik setelah pemberian PGM (Tabel 2).

Tabel 1. Karakteristik posyandu dan desa/ kelurahan yang digunakan sebagai unit analisis

\begin{tabular}{|c|c|c|c|c|c|c|c|c|c|c|}
\hline \multirow[t]{2}{*}{$\begin{array}{c}\text { Karekteristik } \\
\text { variabel }\end{array}$} & \multicolumn{2}{|c|}{$\begin{array}{c}\text { Kota } \\
\text { Mataram }\end{array}$} & \multicolumn{2}{|c|}{$\begin{array}{c}\text { Lombok } \\
\text { Barat }\end{array}$} & \multicolumn{2}{|c|}{$\begin{array}{l}\text { Lombok } \\
\text { Tengah }\end{array}$} & \multicolumn{2}{|c|}{$\begin{array}{l}\text { Lombok } \\
\text { Timur }\end{array}$} & \multicolumn{2}{|c|}{ Jumlah } \\
\hline & $\mathbf{n}$ & $\%$ & $\mathbf{n}$ & $\%$ & $\mathbf{n}$ & $\%$ & $\mathbf{n}$ & $\%$ & $\mathbf{n}$ & $\%$ \\
\hline \multicolumn{11}{|l|}{ Posyandu } \\
\hline Jumlah & 61 & 11,44 & 66 & 12,38 & 160 & 30,02 & 246 & 46,15 & 533 & 100 \\
\hline \multicolumn{11}{|l|}{ Strata posyandu } \\
\hline Pratama & 1 & 1,64 & 15 & 22,73 & 12 & 7,50 & 54 & 21,95 & 82 & 15,38 \\
\hline Madya & 15 & 24,59 & 44 & 66,67 & 145 & 90,63 & 124 & 50,41 & 328 & 61,54 \\
\hline Purnama & 38 & 62,30 & 7 & 10,61 & 2 & 1,25 & 65 & 26,42 & 112 & 21,01 \\
\hline Mandiri & 7 & 11,48 & 0 & 0,00 & 1 & 0,63 & 3 & 1,22 & 11 & 2,06 \\
\hline Jumlah & 61 & 11,44 & 66 & 12,38 & 160 & 30,02 & 246 & 46,15 & 533 & 100 \\
\hline \multicolumn{11}{|l|}{ Desa/ kelurahan } \\
\hline Siaga & 9 & 100 & 7 & 70 & 23 & 92 & 24 & 85,71 & 63 & 87,50 \\
\hline Bukan siaga & 0 & 0 & 3 & 30 & 2 & 8 & 4 & 14,29 & 9 & 12,50 \\
\hline Jumlah & 9 & 12,5 & 10 & 13,89 & 25 & 34,72 & 28 & 38,89 & 72 & 100 \\
\hline \multicolumn{11}{|c|}{ Kelompok gizi masyarakat (KGM) } \\
\hline Jumlah & 9 & 12,50 & 10 & 13,89 & 25 & 34,72 & 28 & 38,89 & 72 & 100 \\
\hline \multicolumn{11}{|c|}{ Keanggotaan KGM } \\
\hline $100 \%$ wanita & 3 & 33,33 & 3 & 30 & 1 & 4 & 1 & 3,57 & 8 & 11,11 \\
\hline $90 \%$ wanita & 3 & 33,33 & 4 & 40 & 3 & 12 & 4 & 14,29 & 14 & 19,45 \\
\hline $80 \%$ wanita & 1 & 11,12 & 2 & 20 & 3 & 12 & 7 & 25,00 & 13 & 18,05 \\
\hline $70 \%$ wanita & 2 & 22,22 & 0 & 0 & 4 & 16 & 8 & $28 ' 57$ & 14 & 19,45 \\
\hline $60 \%$ wanita & 0 & 0 & 1 & 10 & 14 & 56 & 8 & 28,57 & 23 & 31,94 \\
\hline Jumlah & 9 & 12,50 & 10 & 13,89 & 25 & 34,72 & 28 & 38,89 & 72 & 100 \\
\hline
\end{tabular}


Tabel 2. Distribusi posyandu berdasarkan kategori kinerja posyandu sebelum dan sesudah pelaksanaan paket gizi masyarakat (PGM) di Provinsi NTB tahun 2011

\begin{tabular}{lcccc}
\hline $\begin{array}{c}\text { Kategori } \\
\text { Kinerja } \\
\text { Posyandu }\end{array}$ & \multicolumn{2}{c}{$\begin{array}{c}\text { Sebelum } \\
\text { Pelaksanaan PGM }\end{array}$} & \multicolumn{2}{c}{$\begin{array}{c}\text { Sesudah } \\
\text { pelaksanaan } \\
\text { PGM }\end{array}$} \\
\cline { 2 - 5 } & $\mathbf{n}$ & $\%$ & $\mathbf{n}$ & $\%$ \\
\hline Baik & 406 & 76,17 & 533 & 100,00 \\
Sedang & 97 & 18,20 & 0 & 0,00 \\
Kurang & 30 & 5,63 & 0 & 0,00 \\
Jumlah & 533 & 100 & 533 & 100 \\
\hline
\end{tabular}

Pengaruh PGM terhadap peningkatan kinerja posyandu juga terlihat dari peningkatan cakupan posyandu berdasarkan hasil penimbangan balita di posyandu dengan melihat cakupan D/S, N/D dan BGM/D pada periode sebelum dan setelah pelaksanaan PGM (Tabel 3).

Pengaruh PGM terhadap peningkatan kinerja posyandu juga terlihat dari peningkatan cakupan posyandu seperti disampaikan oleh responden di tingkat desa/ kelurahan, puskesmas, dan kabupaten/ kota.

“.... D/S desa sekitar 85\%, sebelum proyek NICE 45\%, sebelum PGM kadang-kadang jumlah balita yang ada (S) 50 ternyata yang datang (D) 20. Sekarang dari jumlah balitanya 60 ternyata yang tidak hadir hanya 1 sampai 2 orang..." (R14)

“.... rata-rata D/S sekarang diatas $80 \%$, sebelumnya rata-rata hanya $50 \%$.... karena ada kegiatan demo masak sehingga sasaran banyak yang datang setiap bulan..”. (R12)

Pengaruh PGM terhadap peningkatan z-score balita yang diukur di desa/ kelurahan lokasi proyek NICE

Nilai z-score balita dengan indeks berat badan menurut umur (BB/U) apabila dibandingkan antara sebelum (pre) dengan sesudah (post) pemberian PGM terlihat perbedaan yang nyata, pada pengukuran nilai z-score pada 7.975 balita dengan indeks $\mathrm{BB} / \mathrm{U}$ sebelum pelaksanaan PGM memiliki nilai mean \pm sd $-0,288237 \pm 1,939739$ sedangkan setelah pelaksanaan PGM nilai mean \pm sd $-1,565396 \pm 1,063036$, dengan rerata selisih sebesar -1,277159. Hasil uji statistik dengan analisis paired t-test menunjukkan adanya pengaruh pemberian PGM terhadap nilai z-score balita indeks BB/U, $(p<0,001 ; 95 \%$ Cl -1,321063-1,233254).

Jumlah balita yang termasuk dalam klasifikasi kasus gizi buruk dan gizi kurang (indeks BB/U) meningkat setelah pelaksanaan PGM, yaitu masingmasing dari $7,06 \%$ menjadi $9,29 \%$ dan $10,96 \%$ menjadi $22,70 \%$. Jumlah balita dengan status gizi lebih menurun dari $13,13 \%$ menjadi $0,23 \%$ setelah pelaksanaan PGM (Tabel 4).

Dari 874 balita yang berstatus gizi kurang, sebanyak 273 orang $(31,24 \%)$ status gizinya dapat dicegah sehingga tidak menjadi gizi buruk. Balita yang berhasil ditanggulangi sehingga terjadi peningkatan status gizi dari status gizi kurang menjadi status gizi baik sebanyak 490 orang $(56,06 \%)$. Sementara itu, balita yang mempunyai status gizi buruk menjadi status gizi kurang sebanyak 158 orang (28,06\%). Status gizi baik dapat dipertahankan sebanyak 3.774 orang $(68,73 \%)$ (Tabel 5).

Setelah 3 tahun pelaksanaan PGM, 4.145 orang $(51,97 \%)$ tidak mengalami perubahan status gizi (tetap), 2.040 balita $(25,58 \%)$ mengalami penurunan status gizi, dan 1.790 balita $(22,45 \%)$ mengalami kenaikan status gizi.

Berdasarkan wawancara mendalam diperoleh informasi responden di tingkat kabupaten/ kota.

“... hasil BGM (bawah garis merah) kita menurun. Terus hasil PSG juga mengalami penurunan, status gizinya menjadi lebih baik,

Tabel 3. Cakupan penimbangan balita di posyandu sebelum dan setelah pelaksanaan paket gizi masyarakat (PGM)

\begin{tabular}{lrrrrrr}
\hline \multirow{2}{*}{ Cakupan Penimbangan } & \multicolumn{3}{c}{ Tahun 2009 } & \multicolumn{3}{c}{ Tahun 2012 } \\
\cline { 2 - 6 } & Januari & Februari & Maret & Januari & Februari & Maret \\
\hline Partisipasi masyarakat (D/S) & $58,11 \%$ & $66,77 \%$ & $59,55 \%$ & $80,21 \%$ & $86,24 \%$ & $82,89 \%$ \\
Keberhasilan program (N/D) & $48,44 \%$ & $47,97 \%$ & $51,13 \%$ & $57,65 \%$ & $56,73 \%$ & $58,06 \%$ \\
Gizi buruk (BGM/D) & $3,76 \%$ & $3,55 \%$ & $3,38 \%$ & $2,58 \%$ & $2,50 \%$ & $2,36 \%$ \\
\hline
\end{tabular}


Tabel 4. Klasifikasi status gizi balita (indeks BB/U) sebelum dan sesudah pelaksanaan paket gizi masyarakat (PGM) di Provinsi NTB

\begin{tabular}{lcccc}
\hline \multirow{2}{*}{$\begin{array}{c}\text { Klasifikasi } \\
\text { status gizi } \\
\text { (indeks BB/U) }\end{array}$} & $\begin{array}{c}\text { Sebelum } \\
\text { Pelaksanaan } \\
\text { PGM }\end{array}$ & \multicolumn{2}{c}{$\begin{array}{c}\text { sesudah } \\
\text { pelaksanaan } \\
\text { PGM }\end{array}$} \\
\cline { 2 - 5 } & $\mathbf{n}$ & $\%$ & $\mathbf{n}$ & $\%$ \\
\hline Lebih & 1.047 & 13,13 & 18 & 0,23 \\
Baik & 5.491 & 68,85 & 5.406 & 67,79 \\
Kurang & 874 & 10,96 & 1.810 & 22,70 \\
Buruk & 563 & 7,06 & 741 & 9,29 \\
Jumlah & 7.975 & 100 & 7.975 & 100 \\
\hline
\end{tabular}

karena disanakan kelas gizi dan disana mereka bisa kumpul bersama, tukar pikiran dan itu menurunkan BGM,..." (R6).

“... masyarakat mendapat pembelajaran melalui kegiatan-kegiatan kelas ibu, kelas gizi, kelas ibu hamil ataupun kelas balita .. PMT penyuluhan diharapkan agar masyarakat bisa melakukan sendiri kepada anaknya dirumah. . Kelas gizi yang dilakukan itu selama 12 hari ..." (R5).

\section{Penilaian input dan proses PGM}

Desa/ kelurahan yang menerima PGM melakukan perencanaan secara partisipatif yang dilakukan oleh kelompok gizi masyarakat yang telah dipilih dalam rapat oleh masyarakat yang dipimpin kepala desa/ lurah dan difasilitasi oleh fasilitator masyarakat (FM). Jumlah anggota kelompok gizi masyarakat terdiri dari 10 orang dengan proporsi jumlah anggota wanita di atas 60\% (Tabel 1).

Keanggotaan KGM ini sudah memenuhi persyaratan pemberi pinjaman $(A D B)(1)$. Hal ini dipertegas oleh pernyataan responden 4 .
“..... ditetapkan oleh $A D B$ ada keterwakilan wanita minimal 60\%. Pada kenyataannya bahkan ada yang $100 \%$ tapi rata-rata di atas $70 \% \ldots "(R 4)$.

Fasilitator masyarakat yang secara khusus ditempatkan untuk mendampingi KGM dalam melakukan kegiatan pemberdayaan gizi masyarakat. Hal ini dinyatakan juga dalam wawancara mendalam oleh responden 1.

“.....FM membantu KGM dalam pelaksanaan kegiatan PGM, kemudian juga sebagai penghubung antara KGM dengan puskesmas dan dinas kesehatan .." (R1).

Proses penyusunan proposal PGM diawali dengan pengumpulan data dan analisis situasi desa (survei mawas diri) tentang kesehatan masyarakat desa yang dilakukan oleh KGM dan difasilitasi oleh FM. Dilanjutkan dengan pembahasan hasil analisisdalam pertemuan dengan masyarakat (musyawarah masyarakat desa) dan menetapkan bersama cara pemecahan masalah dengan mempertimbangkan potensi desa dalam bentuk rencana kerja KGM atau proposal PGM. Hal ini juga dinyatakan oleh responden 5 .

“....masyarakat itu berdiskusi, mengkaji apa yang menjadi masalah tingkat desa. Kemudian berembuk (=musyawarah) membuat prioritas yang bisa dibiayai oleh PGM... Dibuat dalam bentuk rencana kegiatan yang dituangkan dalam proposal .. Namun dalam penyusunan proposal ada rambu-rambu kegiatan yang boleh dan yang tidak boleh ,..." (R5).

Tabel 5. Pengaruh PGM terhadap perubahan status gizi balita (indeks BB/U) pada pre test dengan post test

\begin{tabular}{lcccccccccc}
\hline \multirow{2}{*}{$\begin{array}{c}\text { Klasifikasi } \\
\text { status gizi }\end{array}$} & $\begin{array}{c}\text { Status gizi balita } \\
\text { salita }\end{array}$ & \multicolumn{8}{c}{ sebelum PGM } & \multicolumn{2}{c}{ Buruk } & \multicolumn{2}{c}{ kurang } & \multicolumn{3}{c}{ Baik } & \multicolumn{2}{c}{ Lebih } \\
\cline { 2 - 11 } \multicolumn{1}{c}{} & $\mathbf{n}$ & $\%$ & $\mathbf{n}$ & $\%$ & $\mathbf{n}$ & $\%$ & $\mathbf{n}$ & $\%$ & $\mathbf{n}$ & $\%$ \\
\hline lebih & 1047 & 100 & 46 & 4,39 & 166 & 15,85 & 831 & 79,37 & 4 & 0,38 \\
baik & 5491 & 100 & 492 & 8,96 & 1213 & 22,09 & 3774 & 68,73 & 12 & 0,22 \\
kurang & 874 & 100 & 109 & 12,47 & 273 & 31,24 & 490 & 56,06 & 2 & 0,23 \\
buruk & 563 & 100 & 94 & 16,70 & 158 & 28,06 & 311 & 55,24 & 0 & 0,00 \\
Total & 7975 & 100 & 741 & 9,29 & 1810 & 22,70 & 5406 & 67,79 & 18 & 0,23 \\
\hline
\end{tabular}


Puskesmas sebagai pembina wilayah tidak terlibat langsung dalam penyusunan proposal PGM. Keterlibatan puskesmas dalam pemantauan dilakukan agar tidak terjadi penyimpangan dana. Hal ini bisa dilakukan karena setiap akan pencairan dana di bank, ketua KGM melakukan konsultasi ke puskesmas agar rencana pencairan dananya diketahui oleh kepala puskesmas.

“...dalam pembuatan paket gizi masyarakat puskesmas tidak pernah dilibatkan hanya FM saja, puskesmas hanya mengetahui dalam pencairan dana.." (R9).

Jumlah dana yang diusulkan dalam setiap PGM tidak melebihi 140 juta. Pencairan dana dibagi menjadi 3 tahap dengan ketentuan di setiap tahapnya telah menyelesaikan minimal $75 \%$ dana pada tahap sebelumnya. Hal ini dipertegas dalam pernyataan responden.

“..... paket gizi semuanya 140 juta di bagi menjadi 3 tahap. Tahap pertama itu 56 juta, tahap kedua itu 42 juta dan tahap ketiga 42 juta.... Apabila pada tahap pertama sudah selesai 75 \% boleh di usulkan tahap kedua begitu selanjutnya apabila tahap kedua sudah selesai $75 \%$ boleh mengusulkan tahap ketiga ..." (R13).

Komponen kegiatan yang terbesar pembiayaannya yang diusulkan KGM termasuk dalam komponen kegiatan peningkatan cakupan posyandu (51,99\%) (Gambar 1).

Proposal akan direview dan dinilai oleh tim teknis kabupaten/ kota (DTT). Jika proposal memenuhi persyaratan, DTT mengirimkan hasil penilaian proposal tersebut ke kepala dinas kesehatan kabupaten selaku manager proyek untuk mendapat persetujuan. Selanjutnya, manager proyek kabupaten/ kota mengirimkan berkas proposal tersebut ke dinas kesehatan provinsi (PPCU) untuk dibuatkan kontrak (surat perjanjian pemberian bantuan/ SPPB). Dana PGM dibayarkan oleh PPCU yang langsung ditransfer ke rekening KGM di bank yang dipilih. Pengiriman dana oleh PPCU dilaksanakan dalam 3 tahap untuk digunakan oleh KGM dalam melaksanakan kegiatan sesuai dengan proposal.

Dalam pengambilan dana PGM tersebut, KGM harus memenuhi beberapa mekanisme dan pencatatan pelaporan yang ada sesuai dengan pedoman pengelolaan keuangan PGM yang dikeluarkan oleh Departemen Kesehatan R.I.

“....awalnya FM membuat RPD (rencana penarikan dana) kemudian setelah jadi RPD dikonsultasikan ke puskesmas oleh Ketua KGM bersama FM dengan membawa rencana kegiatan yang dilaksanakan bulan ini.. Kepala Puskesmas akan tanda tangan kalau sudah menyetujui. KGM mengambil uang ke bank,... bendahara KGM mencatat di buku kas harian..

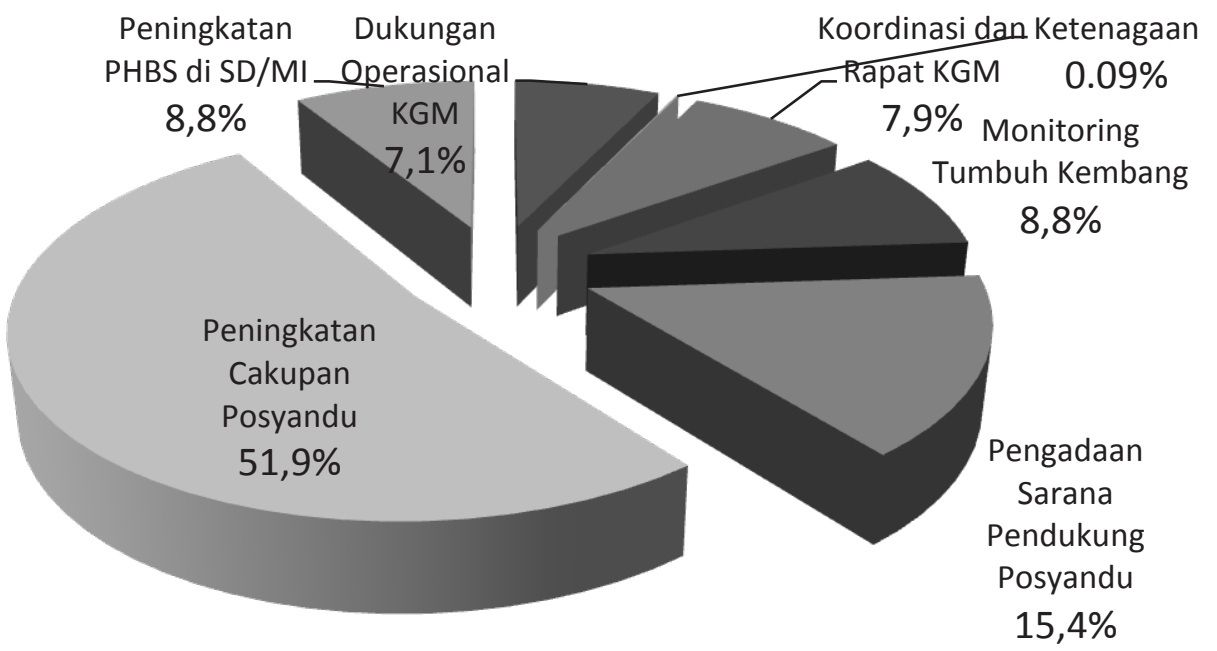

Gambar 1. Proporsi anggaran proposal paket gizi masyarakat di 72 desa/ kelurahan sampel penelitian 
baru pembagian tugas antar anggota KGM...." (R13).

Berdasarkan hasil wawancara mendalam kepada responden, baik di tingkat provinsi sampai desa/ kelurahan diperoleh informasi mengenai faktor pendukung dari kelancaran pelaksanaan PGM di lokasi penelitian.

Sebelum PGM direncanakan, terlebih dahulu dilakukan pelatihan bagi FM dan KGM baik yang dilakukan di provinsi maupun kabupaten/ kota dan puskesmas.

“...untukyang mendukung, tentu saja kemampuan dari KGM yang mengelola PGM, kemudian FM kemampuannya didalam mengkoordinir desadesanya. Kemudian juga peran puskesmas di dalam membina penyuluhan kemudian juga peran kabupaten di dalam membina kegiatan di tingkat desa...." (R1).

Sebelum menerima PGM, kepala desa/ kelurahan menyatakan kesanggupan menerima dan melaksanakan PGM. Hal ini berdampak pada keharusan bagi tokoh masyarakat (kepala desa/ kelurahan) untuk bersama masyarakat melaksanakan PGM ini di samping adanya keterlibatan sektor terkait yang ada.

“.... adanya surat pernyataan dari kepala desa bahwa sanggup menerima dan mengelola paket gizi masyarakat... adanya peran serta dari lintas sektor dalam ini adalah ketelibatan dari BPMD, dinas pendidikan, kemudian dari ketahanan pangan, sosial budaya dan melakukan bimbingan secara teknis...." (R5).

Anggota KGM relatif sebagian besar merangkap sebagai kader. Kedudukannya sebagai kader posyandu mempermudah untuk memobilisasi sasaran dan menjalin hubungan dengan masyarakat. Hal ini diperkuat dengan hasil wawancara mendalam dengan responden.

"..... yang aktif itu kadernya, maksudnya anggota KGM nya aktif .. komunikasi jadi lancar..." (R9).

".... keterlibatan kadus disini sangat dibutuhkan, termasukjuga tokoh agamanya. Keterlibatannya sering di khotbah-khotbah jumat untuk menyampaikan tentang kesehatan..." (R15).

Kendala yang dialami dalam pengelolaan PGM adalah mekanisme dan prosedur pencairan dana yang dipersyaratkan Proyek NICE cukup rumit untuk dikerjakan oleh KGM. Hal ini seperti disampaikan pada wawancara mendalam dengan responden.

“... pertama, keterlambatan dana, berkasberkas untuk pencairan dana tidak lengkap, kesalahan di dalam berkas-berkas seperti kesalahan no rekening dan sebagainya. Disamping pengelolanya sering ganti-ganti misalnya bendaharanya....." (R1).

\section{BAHASAN}

Hasil penelitian ini membuktikan kinerja posyandu meningkat setelah PGM dilaksanakan oleh KGM. Hal ini didukung dengan uji statistik yang mendapat nilai $p<0,001$ dengan $95 \% \mathrm{Cl}$ $9,885763-11,05232$. Jika dilihat dari perkembangan kinerja posyandu setelah pemberian PGM, kinerja posyandu di posyandu sampel $100 \%$ termasuk kategori posyandu dengan kinerja baik (Tabel 2).

Hasil penelitian ini menunjukkan komponen kegiatan dalam proposal PGM (Gambar 1) sebagian besar $(51,99 \%)$ dana diperuntukkkan untuk peningkatan cakupan posyandu dan terdapat $15,37 \%$ dana untuk pengadaan sarana pendukung posyandu. Kajian kualitatif juga menyimpulkan bahwa pendekatan yang dilakukan KGM dalam meningkatkan cakupan posyandu dengan melakukan persiapan mobilisasi sasaran sebelum kegiatan posyandu dan melakukan kegiatan kunjungan rumah bagi balita yang tidak hadir posyandu. Di samping adanya dukungan kepala dusun dan tokoh agama dalam menggerakkan sasaran.

Cakupan penimbangan balita setelah pelaksanaan PGM mengalami peningkatan. Cakupan tingkat partisipasi masyarakat (D/S) sudah mencapai target indikator dampak jangka pendek yaitu cakupan kunjungan posyandu serendah- rendahnya $80 \%$, sementara cakupan 
D/S setelah pelaksanaan PGM di atas $80 \%$. Tingkat pertumbuhan balita (N/D) juga meningkat sementara jumlah balita yang memiliki berat di bawah garis merah (BGM) juga terus menurun dan masih kurang dari 5\% (Tabel 3).

Selama ini masalah yang berkaitan dengan kunjungan posyandu antara lain tersedianya dana operasional untuk menggerakkan kegiatan posyandu, tersedianya sarana dan prasarana serta bahan penyuluhan yang belum memadai, pengetahuan kader masih rendah dan kemampuan petugas dalam pemantauan pertumbuhan serta konseling masih lemah, masih kurangnya pemahaman keluarga dan masyarakat akan manfaat posyandu serta terbatasnya pembinaan kader.

Berdasarkan proposal PGM, diketahui bahwa dana peningkatan cakupan posyandu melingkupi kegiatan yang diusulkan dalam bentuk penyuluhan dengan metode demonstrasi pembuatan makanan sehat (PMT-penyuluhan), kunjungan rumah oleh kader dalam rangka peningkatan kunjungan sasaran, operasional kader dan posyandu, pengadaan alat pendukung posyandu, penyegaran kader, penyuluhan kelompok (ibu balita, ibu hamil, ibu menyusui, tokoh agama/ tokoh masyarakat), pertemuan kader sesudah kegiatan posyandu, kelas gizi (ibu hami, ibu balita, ibu menyusui dan balita), lomba posyandu/ balita sehat, pemanfaatan pekarangan posyandu, sweeping sasaran posyandu (mobilisasi sasaran), dan dana bimbingan KGM ke posyandu. Dana pengadaan sarana pendukung posyandu kegiatannya diusulkan dalam bentuk pengadaan perlengkapan yang dibutuhkan di posyandu seperti pengadaan meubeler (meja dan kursi), papan data, alat permainan edukatif (APE), alat masak, alat kebersihan dan ATK posyandu.

Dengan menggunakan dana tersebut posyandu yang berada di desa/ kelurahan penerima PGM cenderung memiliki sarana dan prasarana yang lebih lengkap. Sasaran kegiatan posyandu akan hadir pada saat kegiatan karena adanya kegiatan PMT Penyuluhan dan kelas gizi disamping adanya kunjungan oleh kader pada $\mathrm{H}-1$ posyandu. Kunjungan kader ke rumah sasaran ditujukan untuk mengingatkan sasaran posyandu (ibu balita, ibu hamil dan ibu menyusui) terhadap jadwal posyandu di wilayahnya di samping untuk pendekatan ke ibu balita yang memiliki anak dengan berat badan di bawah garis merah pada KMS (BGM) dan balita atau ibu yang tidak hadir di posyandu.

Hasil penelitian ini sejalan dengan penelitian di Padang Pariaman yang menyatakan bahwa terdapat perbedaan nyata kinerja posyandu dengan strata posyandu, yang diketahui bahwa Posyandu Purnama dan Mandiri kinerjanya lebih bagus daripada Posyandu Madya dan Pratama (8).

Hasil penelitian ini membuktikan bahwa pemberian PGM tidak terbukti memiliki pengaruh terhadap peningkatan status gizi balita. Nilai z-score balita indeks BB/U berbeda secara bermakna bila dibandingkan antara nilai z-score sebelum dengan sesudah PGM dilaksanakan oleh KGM. Nilai z-score menurun (ke arah negatif) setelah pelaksanaan PGM. Uji statistik diperoleh nilai $\mathrm{p}<0,001$ dengan $95 \% \mathrm{Cl}-1,321063-1,233254$. Jika dilihat dari perkembangan status gizi balita setelah pemberian PGM (Tabel 5), sebagian besar balita tidak mengalami perubahan status gizinya/ tetap $(51,97 \%)$ setelah pelaksanaan PGM.

Tidak ada dukungan dana untuk kegiatan PMT pemulihan untuk balita gizi kurang dan gizi buruk. Hal ini disebabkan dalam pedoman penggunaan PGM tidak diperkenankan penggunaan PGM untuk PMT-pemulihan. Sementara berdasarkan hasil pre test (sebelum pelaksanaan PGM) terdapat 10,96\% balita yang mengalami gizi kurang dan 7,06\% mengalami gizi buruk, sedangkan intervensi dalam PGM cenderung dititikberatkan pada pendidikan gizi yang salah satu kegiatannya melalui PMTpenyuluhan dan kelas gizi. Perubahan perilaku masyarakat yang diharapkan melalui pendidikan gizi, membutuhkan waktu sehingga dapat memberikan pengaruh pada peningkatan status gizi sebagai dampak jangka panjang Proyek NICE. Pencairan dana PGM tahap ketiga (terakhir) sebanyak 18,06\% desa/ kelurahan dilakukan oleh KGM pada Bulan Oktober 2011 dan 81,94\% KGM mencairkan pada Bulan November 2011 sementara pengambilan data post test dilakukan padan Bulan Januari s.d. Maret 2012, sehingga waktu yang tersedia untuk melihat perubahan perilaku relatif singkat. 
Hasil di atas berdasarkan penelitian di Bogor dengan intervensi yang berbeda memberikan gambaran bahwa intervensi program gizi di posyandu memiliki dampak yang signifikan terhadap status gizi $(\mathrm{BB} / \mathrm{U})$ dari anak bawah lima tahun. Intervensi pendidikan sekali dalam dua minggu gizi selama 5 bulan di posyandu dan berkebun di rumah responden, memiliki dampak yang signifikan terhadap status gizi (BB/U) dari anak di bawah lima tahun tetapi tidak memiliki efek signifikan pada status gizi balita menurut indeks TB/ $U$ dan BB/ TB. Dengan demikian waktu yang diperlukan untuk mengetahui dampak terhadap status gizi (indeks $\mathrm{BB} / \mathrm{U}$ ) setelah intervensi pendidikan gizi melalui posyandu selama 5 bulan (9).

Kekurangan gizi pada anak secara langsung disebabkan makanan anak yang tidak seimbang dan penyakit infeksi yang mungkin diderita anak. Selain penyebab langsung, terdapat penyebab tidak langsung pada status gizi balita yaitu ketahanan pangan di keluarga, pola pengasuhan anak, serta pelayanan kesehatan dan kesehatan lingkungan. Ketiga faktor tidak langsung tersebut saling berkaitan dan bersumber pada akar masalah yaitu pendidikan dan ekonomi keluarga serta ketrampilan memanfaatkan sumber daya keluarga dan masyarakat (10). Sementara PGM cenderung menitikberatkan pada peningkatan pendidikan, pengetahuan dan ketrampilan keluarga dalam pola pengasuhan anak serta peningkatan pemberdayaan wanita dan keluarga melalui kegiatan seperti kelas gizi, beternak dan budidaya ikan. PGM tidak mampu mengatasi penyebab langsung kekurangan gizi tanpa didukung komponen kegiatan lain Proyek NICE serta keterlibatan sektor terkait secara terpadu dalam penanganan masalah gizi.

Prevalensi balita dengan status gizi kurang setelah pelaksanaan PGM masih di bawah target indikator dampak jangka panjang Proyek NICE (kurang dari 20\%). Hasil ini sama dengan penelitian dampak World Vision Project terhadap status gizi balita di Kenya, yang menunjukkan prevalensi gizi kurang di daerah intervensi proyek lebih tinggi dari rata-rata nasionalnya $(22,2 \%)$. Dari penelitian tersebut juga diketahui bahwa prevalensi gizi kurang balita tersebut dipengaruhi oleh situasi kekeringan yang berulang terjadi di daerah proyek sehingga mengakibatkan kekurangan pangan dan asupan makanan yang tidak memadai dalam jangka waktu lama di daerah tersebut. Kegiatan World Vision Project meliputi bantuan pangan, rehabilitasi, pengembangan sarana dan program kesehatan, penyediaan air bersih dan sehat serta perbaikan pemukiman, disamping intervensi lain di bidang keamanan pangan, pengembangan usaha mikro, pelatihan kejuruan dan keagamaan (11).

Komponen kegiatan lain dalam Proyek NICE selain pemberdayaan gizi masyarakat, adalah pengembangan institusi untuk kebijakan, program dan surveilan gizi, pelayanan gizi terpadu, fortifikasi dan komunikasi gizi serta penguatan manajemen program. Salah satu upaya yang perlu didorong dalam kegiatan Proyek NICE adalah implementasi rencana aksi daerah pangan dan gizi (RADPG) yang telah disusun oleh kabupaten/ kota sebagai arah dan kebijakan daerah dalam pembangunan di bidang pangan dan perbaikan gizi, disamping menggambarkan rencana kegiatan dan peran dari masing-masing lintas sektoral Pemerintah, swasta dan lembaga dalam penanganan masalah gizi di Provinsi NTB.

Sebelum pelaksanaan PGM ( $\mathrm{n}=7.975$ orang) balita berumur $0-1$ tahun sebanyak 5.243 orang $(65,74 \%), 2.730$ orang $(34,23 \%)$ berumur $1-2$ tahun dan 2 orang $(0,03 \%)$ berumur 3 tahun, sedangkan saat pengukuran setelah pelaksanaan PGM ( $n=7.975$ orang) sebanyak 4.634 orang $(58,11 \%)$ berusia 4 tahun dan 3.341 orang $(41,89 \%)$ berumur 5 tahun. Nilai z-score berat badan menurut umur pada balita mengalami penurunan drastis sejak usia di atas 6 bulan dan pada usia 2 sampai 5 tahun pada negara-negara di Asia berada pada kisaran -2,00 sampai $-1,25$. Terjadinya penurunan pertumbuhan fisik, perkembangan otak dan tingkat pendapatan penduduk yang terjadi secara drastis dan meluas dalam periode 2 tahun pertama kehidupan manusia. Hal ini terjadi pada negara yang berkembang yang pembangunannya belum berhasil mengentaskan kemiskinan dan meningkatkan kesejahteraan, serta mengabaikan peran gizi dalam pembangunan manusia (12).

Setelah pelaksanaan PGM, dari 741 balita yang masih mengalami gizi buruk terdiri dari 461 
orang $(62,21 \%)$ berumur 4 tahun dan 280 orang $(37,79 \%)$ berumur 5 tahun. Sedangkan balita yang masih berstatus gizi kurang sebanyak 1.810 orang yang terdiri dari 1.015 orang $(56,08 \%)$ berumur 4 tahun dan 795 orang $(43,92 \%)$ berumur 5 tahun. Masuk usia 3 tahun, umumnya tubuh anak mulai kelihatan lebih langsing, karena perkembangan lemaknya sudah jauh berkurang. Berat badan kurang bisa disebabkan asupan gizi yang kurang, aktivitas anak yang berlebih, atau ada penyakit yang melatarinya sehingga asupan makanannya tidak terserap secara optimal. Anak usia ini sedang giatgiatnya bereksplorasi, sehingga kenaikan BB-nya tidak sesuai dengan pertumbuhan normal karena energi banyak yang terbuang. Di samping adanya picky eater (suka pilih-pilih makanan) pada golongan usia dan faktor pertumbuhan gigi yang menyebabkan anak tidak mau mengunyah makanan (13).

Beberapa kondisi yang menyebabkan usia rawan gizi dan kesehatan pada balita adalah balita masih berada dalam masa transisi dari makanan bayi ke makanan orang dewasa, perhatian ibu berkurang kepada anak balita karena ibu bekerja atau sudah mempunyai adik dan pada usia ini anak sudah mulai bermain di tanah dan sudah bisa main di luar rumah sendiri, sehingga terpaksa lebih terpapar dengan lingkungan yang kotor dan kondisi yang memungkinkan untuk terinfeksi dengan berbagai penyakit (14). Anak yang berumur 1-3 tahun akan mengalami pertambahan berat sebanyak $2-2,5 \mathrm{~kg}$, sedangkan pertambahan berat anak usia prasekolah (4-6 tahun) berkisar antara 0,7 - 2,3 kg (15).

Peningkatan kinerja posyandu setelah pelaksanaan PGM yang salah satunya ditandai dengan meningkatnya cakupan kehadiran di posyandu (D/S) belum mampu meningkatkan status gizi balita. Hasil ini diperkuat dengan penelitian di Surabaya bahwa ditemukan tidak ada hubungan yang signifikan antara pertumbuhan balita (status gizi) dengan kehadiran di Posyandu $(p>0,05)(16)$. Penelitian di Padang Pariaman menyimpulkan bahwa terdapat hubungan yang nyata antara pelayanan kesehatan dan KB, pelaporan dan tindak lanjut serta output kinerja posyandu dengan jumlah balita berstatus gizi baik dan kurang (8). Penelitian di Pakistan menegaskan bahwa kekurangan gizi baik akut dan kronis berkaitan dengan akibat asupan zat gizi yang kurang atau rendah kualitasnya. Kekurangan ini mengakibatkan anakanak mudah terkontaminasi penyakit diare, infeksi pernafasan akut dan infeksi lain senyawa yang lebih lanjut. Kondisi ini berdampak pada status kesehatan anak. Dalam kasus gizi buruk dengan prevalensi tinggi, terjadi akibat derajat kesehatan yang buruk dan kemiskinan (17).

Hasil penelitian menunjukkan bahwa PGM merupakan intervensi berbasis pemberdayaan masyarakat dalam menanggulangi masalah gizi yang ada, hasil ini sejalan dengan penelitian di Kenya yang menyimpulkan perlunya penanganan masalah gizi secara terpadu baik pemerintah, swata dan LSM. Karena ditemukan bahwa prevalensi balita gizi buruk sebagai akibat kurangnya pemberian ASI ekslusif, pemberian MP-ASI, jarak melahirkan dan pelayanan kesehatan serta rendahnya sosial- ekonomi (11). Penanggulangan masalah gizi kurang perlu dilakukan secara terpadu antar departemen dan profesi, melalui upaya-upaya peningkatan pengadaan pangan, penganekaragaman produksi dan konsumsi pangan, peningkatan status sosial ekonomi, pendidikan, dan kesehatan masyarakat serta peningkatan hasil pertanian dan teknologi pangan (18). Di samping itu, PGM yang diberikan tidak memperbolehkan komponen kegiatan intervensi langsung penanganan gizi buruk yang ada melalui PMT Pemulihan dan MP-ASI (1).

KGM yang mengelola PGM dan menjadi sampel penelitian diketahui memiliki keanggotaan dengan proporsi wanita di atas $60 \%$ (Tabel 1), sesuai dengan ketentuan yang dipersyaratkan oleh pemilik dana pinjaman (ADB) (1). Jenis kegiatan yang diusulkan oleh KGM dalam proposal PGM (Gambar 1) terbukti merupakan jenis kegiatan yang termasuk dalam kategori kegiatan yang diperbolehkan atau sesuai dengan pedoman PGM. Proporsi terbesar termasuk dalam komponen kegiatan peningkatan cakupan posyandu (1). Permasalahan gizi buruk anak balita, kekurangan gizi dan masalah kesehatan lainnya menyangkut kesehatan ibu dan anak akan mudah dihindari jika posyandu kembali diprogramkan secara menyeluruh (19). 
Berdasarkan wawancara mendalam diketahui bahwa proposal PGM disusun berdasarkan permasalahan dan potensi desa/ kelurahan yang ada. Keterlibatan kepala desa/ lurah beserta tokoh agama dan masyarakat terlihat dalam musyawarah masyarakat desa untuk menetapkan rencana kegiatan yang akan disusun. Pelaksanaan suatu upaya kesehatan tidak didukung oleh suatu perencanaan yang baik, maka akan sulit dapat diharapkan tercapainya tujuan dari upaya kesehatan tersebut (20). Melihat dari proses perencanaan PGM telah menggambarkan pemberdayaan masyarakat. Pemberdayaan masyarakat adalah segala upaya fasilitasi yang bersifat non instruktif guna meningkatkan pengetahuan dan kemampuan masyarakat agar mampu mengindentifikasi masalah, merencanakan dan melakukan pemecahannya dengan memanfaatkan potensi setempat dan fasilitas yang ada, baik dari instansi, lintas sektoral maupun LSM dan tokoh masyarakat (21).

Hasil penelitian ini menunjukkan bahwa pembinaan dan pemantauan dilaksanakan secara berkala oleh dinas kesehatan provinsi (PPCU), dinas kesehatan kabupaten/ kota (DPIU), puskesmas dan fasilitator masyarakat. Sesungguhnya essensi pokok dari supervisi (pembinaan dan pemantauan) ialah bagaimana dapat menjamin pelaksanaan berbagai kegiatan yang telah direncanakan secara benar dan tepat dalam arti lebih efektif dan efesien, sedemikian rupa sehingga tujuan yang telah ditetapkan dapat dicapai dengan memuaskan (20). Faktor pendukung pelaksanaan PGM di antaranya kemampuan sumber daya manusia (kelompok gizi masyarakat) dalam mengelola PGM, adanya dukungan aparat desa/ lurah/ kepala lingkungan/ dusun, dukungan lintas sektoral terkait dan keterpaduan dengan kegiatan/ bantuan lainnya (PNPM Mandiri, GSC, dan dana daerah). Kemampuan pengelola di tingkat desa/ kelurahan (KGM) menentukan keberlanjutan kegiatan pemberdayaan masyarakat dalam perbaikan gizi ini karena lokasi desa/ kelurahan penerima PGM juga menjadi lokasi program sejenis seperti PNPM - mandiri pedesaan/ perkotaan dan generasi sehat dan cerdas (GSC) sehingga diperlukan kemampuan KGM dalam mengelola dan memanfaatkan dana yang ada. Kegiatan inovatif yang menghasilkan dana bergulir melalui budidaya ikan, beternak itik, kambing, dan jala ikan serta lainnya yang mulai dilakukan pada tahap ketiga pencairan PGM hasilnya baru dapat dirasakan pada akhir Proyek NICE sehingga dana tersebut menjadi modal bagi Posyandu dan KGM dalam melanjutkan kegiatannya. Kendala yang dihadapi mencakup latar belakang pendidikan pengelola PGM dan keterlambatan pencairan dana bantuan.

\section{KESIMPULAN DAN SARAN}

Kinerja posyandu meningkat secara signifikan setelah PGM dilaksanakan oleh kelompok gizi masyarakat. Terdapat perbedaan bermakna Nilai z-score balita indeks BB/U sesudah pelaksanaan PGM. Nilai Z-score cenderung ke arah negatif setelah pelaksanaan PGM sehingga PGM hanya mampu meningkatkan status gizi balita sebesar $22,45 \%$. Faktor pendukung pelaksanaan PGM di antaranya kemampuan sumber daya manusia (kelompok gizi masyarakat) dalam mengelola PGM, adanya dukungan aparat desa/ lurah/ kepala lingkungan/ dusun, dukungan lintas sektoral terkait dan keterpaduan dengan kegiatan/ bantuan lainnya (PNPM Mandiri, GSC, dan dana daerah). Sedangkan kendala yang dihadapi dalam pelaksanaan PGM kemampuan KGM pengelolaan administrasi keuangan dan keterlambatan pencairan dana bantuan.

Diperlukan pembinaan kepada KGM dan perbaikan pengelolaan administrasi keuangan dalam pelaksanaan PGM. Diperlukan pula pembinaan kepada seluruh stakeholder (KGM, aparat, dan masyarakat) untuk dapat meningkatkan akses dan ketersediaan pangan bagi balita dan keluarga melalui kegiatan produksi pangan sesuai kondisi alam (misalnya beternak, berkebun, tambak ikan dan usaha jala bergulir), dengan memanfaatkan dana dari pihak lain (PNPM Mandiri, GSC dan dana daerah).

\section{RUJUKAN}

1. Departemen Kesehatan RI. Pedoman umum proyek perbaikan gizi melalui pemberdayaan masyarakat. Jakarta : Direktorat Jenderal Bina Kesehatan Masyarakat.; 2008 
2. Dinas Kesehatan Provinsi NTB. Laporan tahunan program perbaikan gizi Provinsi NTB 2010. Mataram : Dinas Kesehatan Provinsi NTB ;2010

3. Wijono, D. Manajemen Mutu Pelayanan Kesehatan. Teori, strategi dan aplikasi. cetakan kedua. Surabaya : Airlangga University Press; 2000

4. Purwanto AE, Sulistyastuti RD. Metode penelitian kuantitatif untuk administrasi publik dan masalah-masalah sosial. Edisi I. Yogyakarta: Gava Media; 2011

5. Kementerian Kesehatan RI. Final report baseline data collection for nutrition improvement through community empowerment (NICE). Jakarta : Direktorat Jenderal Bina Kesehatan Masyarakat; 2010

6. Sugiyono. Metode penelitian kuantitatif, kualitatif dan r \& d. Bandung : Alfa Beta ; 2006

7. Moeleong LJ. Metodologi penelitian kualitatif. Edisi Revisi. Bandung : Remaja Rosda Karya; 2005

8. Kasmita, Khomsan A, Sukandar D.,Susanto D. Kinerja posyandu dan status gizi anak balita di Kabupaten Padang Pariaman Propinsi Sumatera Barat. Media Gizi dan Keluarga. 2000; XXIV (2) : $1-10$.

9. Sukandar D, Khomsan A, Anwar F, Riyadi $H$ Mudjajanto ES. Health and nutrition status of children under five years in posyandu nutrition program. Journal of Nutrition and Food. 2010; 5(3):171-177

10. Soekirman. IImu gizi dan aplikasinya: untuk keluarga dan masyarakat. Jakarta : Departemen Pendidikan Nasional ; 2000

11. Macharia CW, Kogi-Makau W, N M Muroki. A comparative study on the nutritional status of children (6-59 months) in a world vision project area and a non project area in Kathonzweni Division, Makueni District Kenya. African Journal of Food Agriculture and Nutritional Development (AJFAND). 2005; 5 (1): 1-13

12. The World Bank. Repositioning nutrition as central to development. Washington: The World Bank; 2006.

13. Kurniasih D, Hilmansyah H, Astuti MP, Imam S. Sehat \& bugar berkat gizi seimbang. Soekirman ed, Afriansyah N ed. Jakarta: Gramedia; 2010

14. Adriani M, \& Wirjatmadi B. Peranan gizi dalam siklus kehidupan. Jakarta: Kencana Prenada Media Group ; 2012

15. Arisman. Gizi dalam daur kehidupan : buku ajar ilmu gizi. Jakarta : Penerbit Buku Kedokteran EGC ; 2007

16. Irwanto, \& Amiranti A. The importance of parenting on growth and development in toddlers. Folia Medica Indonesiana. 2010 ; 46 (4) : 237-240

17. Lodhi, HS, Ur-Rehman M, Lodhi FS, Wazir S, Jadoon $\mathrm{H}$. Assessment of nutritional status of 1-5 year old children in An Urban Union Council of Abbottabad. J Ayub Med Coll Abbottabad. 2010; 22 (3) ; 124-127

18. Almatsier S. Prinsip dasar ilmu gizi. Jakarta: PT. Gramedia Pustaka Utama ; 2009

19. Adisasmito W. Sistem kesehatan. Cetakan ke-3. Jakarta : PT Raja Grafindo Persada; 2010

20. Azwar, A. Pengantar administrasi kesehatan edisi ketiga. Jakarta: Bina Rupa Aksara; 2010.

21. Departemen Kesehatan, UNICEF. Panduan umum pemberdayaan masyarakat di bidang kesehatan ibu dan anak. Jakarta : Departemen Kesehatan RI bekerjasama dengan UNICEF; 1999. 